\title{
Correction: GPR50 is the mammalian ortholog of Mel1c: Evidence of rapid evolution in mammals
}

\author{
Laurence Dufourny ${ }^{1 \dagger}$, Anthony Levasseur ${ }^{2 \dagger}$, Martine Migaud ${ }^{1}$, Isabelle Callebaut ${ }^{3}$, Pierre Pontarotti ${ }^{2}$, \\ Benoit Malpaux ${ }^{1 *}$ and Philippe Monget ${ }^{1 *}$
}

\section{Correction}

The core of the text as well as the legends remain the same as in our article [1] since the changes provided here do not change any of the outcomes of the former study including the results and our related conclusions. However, new figure files are provided since some arrows and stars have been previously misplaced in figures three A (figure 1) and four (figure 2), and the for-

\begin{tabular}{|c|c|}
\hline & TM1 \\
\hline \multirow[t]{2}{*}{$\begin{array}{l}\text { bovine rhodopsin } \\
\text { human MT1 } \\
\text { human MT2 } \\
\text { human GPR50 }\end{array}$} & 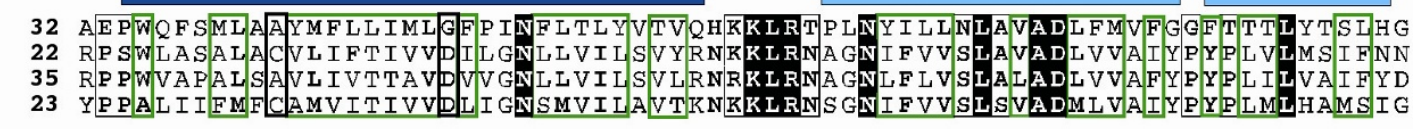 \\
\hline & TM4 \\
\hline $\begin{array}{l}\text { bovine rhodopsin } \\
\text { human MT1 } \\
\text { human MT2 } \\
\text { human GPR50 }\end{array}$ & 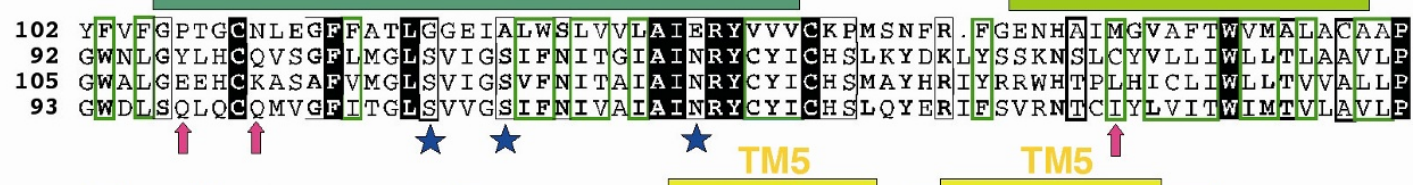 \\
\hline $\begin{array}{l}\text { bovine rhodopsin } \\
\text { human MT1 } \\
\text { human MT2 } \\
\text { human GPR50 }\end{array}$ & 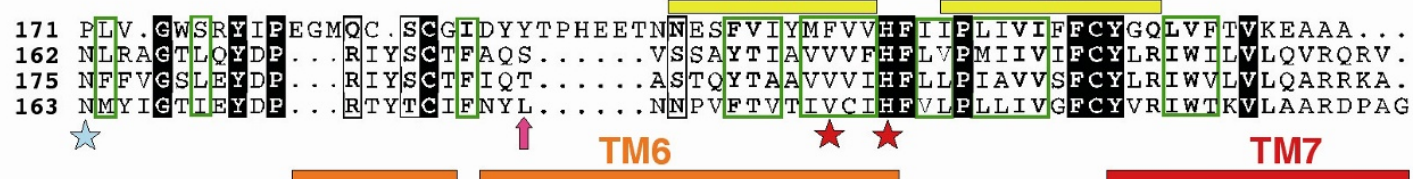 \\
\hline $\begin{array}{l}\text { bovine rhodopsin } \\
\text { human MT1 } \\
\text { human MT2 } \\
\text { human GPR50 }\end{array}$ & 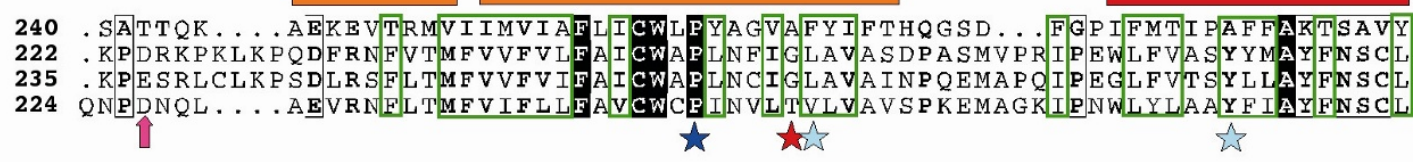 \\
\hline $\begin{array}{l}\text { rhodopsin } \\
\text { MT1 } \\
\text { MT2 } \\
\text { GPR50 }\end{array}$ & 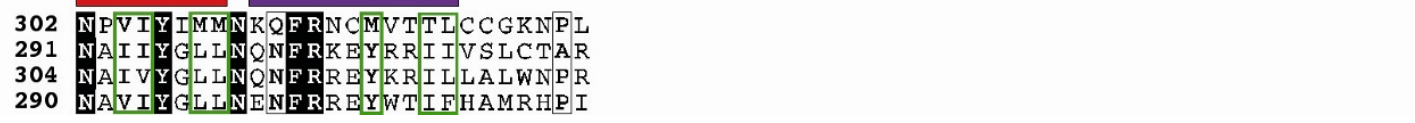 \\
\hline $\begin{array}{l}\text { Figure } 1 \text { Phylog } \\
\text { MT2, and Mel1c } \\
\text { based on Neighb } \\
\text { letters corresponc }\end{array}$ & $\begin{array}{l}\text { tic analysis of the GPR50/MT1/MT2/Mel1c genes. (A) Overall phylogenetic tree showing } 3 \text { groups o } \\
\text { s and the animal orders where each branch is expressed. The trees (npl) are the fusion of three phylo } \\
\text { joining, maximum Parsimony and maximum Likelihood (see "Materials and Methods" section for furthe } \\
\text { the name given to the branches for the likelihood ratio tests (B) Phylogenetic tree of GPR50 genes. Pl }\end{array}$ \\
\hline
\end{tabular}

\footnotetext{
* Correspondence: malpaux@tours.inra.fr; monget@tours.inra.fr

† Contributed equally

'Physiologie de la Reproduction et des Comportements, UMR 6175 INRA-

CNRS-Université François Rabelais de Tours-Haras Nationaux, 37380 Nouzilly,

France

Full list of author information is available at the end of the article
}

\section{Biomed Central}

(C) 2012 Dufourny et al; licensee BioMed Central Ltd. This is an Open Access article distributed under the terms of the Creative Commons Attribution License (http://creativecommons.org/licenses/by/2.0), which permits unrestricted use, distribution, and reproduction in any medium, provided the original work is properly cited. 


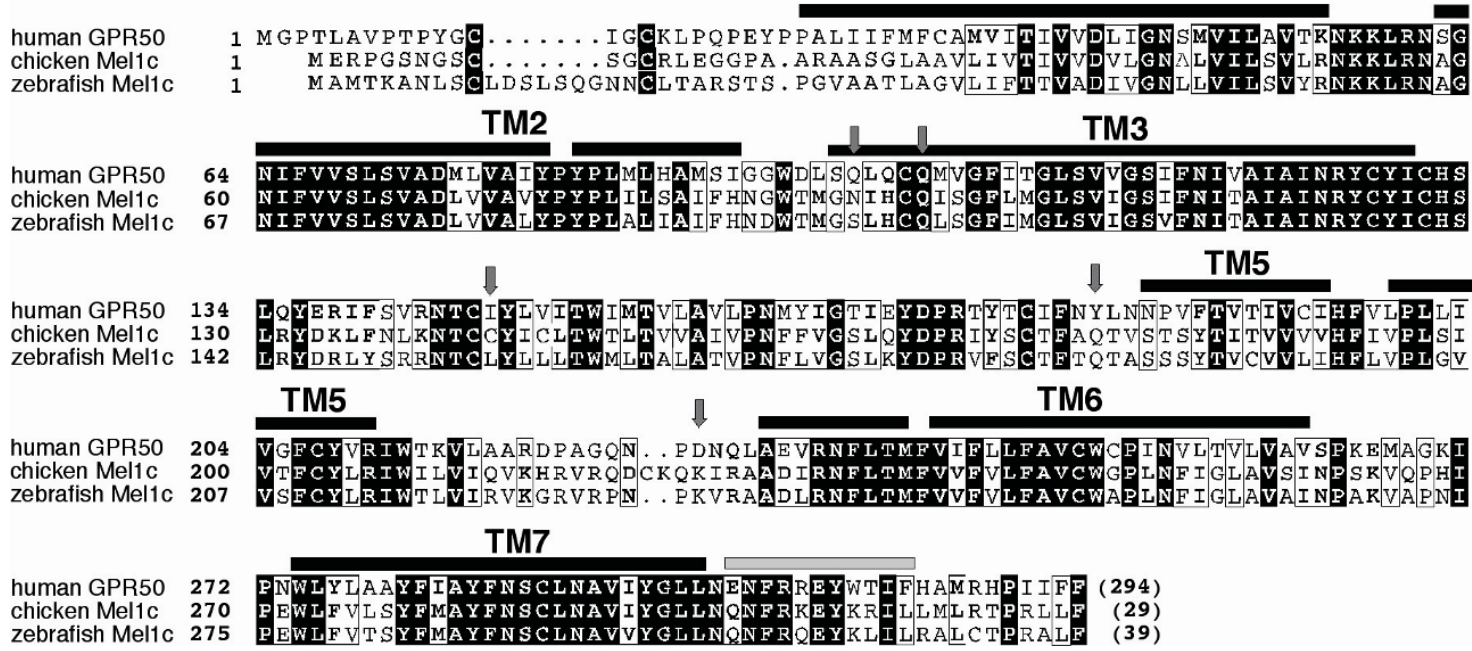

Figure 2 Synteny of Mel1c/GPR50 genes and neighbours in vertebrate genomes. Note that genes are found on chromosome 5 in zebra fish and on chromosome 4 in chicken while they are found on chromosome $X$ in other depicted species. Please note that synteny is mostly conserved for bHLHPAS, 2610030H06 RIK, Mel1c, HMG2A, CD99, and myotubularin related protein in opossum and mammalian species despite the integration of new genes coding for hypothetical proteins (opossum, chimpanzee, cow), ribosomal proteins (dog, chimpanzee, man), NGFI-A binding protein (chimpanzee, man), Utbf (mouse) and MAGE (cattle) proteins. It is also of note that several genes surrounding Mel1c in zebra fish (pdcd8, nono, and the two hypothetical proteins) present high identities with genes found on chromosome $\mathrm{X}$ in mouse but not in the GPR50 locus (unpublished data). p.d.: predicted gene. Chrm: chromosome.

\begin{tabular}{|c|c|c|}
\hline \multicolumn{3}{|r|}{$\mathrm{S} \mathbf{R} S \mathrm{~S} \mathbf{S} \mathrm{A}$} \\
\hline GPR50 & 397 & $\mathrm{R}|\mathrm{K}| \mathrm{S} \mathbf{A}|\mathbf{S} \mathrm{T}| \mathbf{H}$ \\
\hline GPR50 & 404 & $\mathrm{H}|\mathbf{K}| \mathrm{S} \mathrm{V}|\mathbf{F}| \mathbf{S} \mid \mathbf{H}$ \\
\hline GPR50 & 411 & $\mathrm{~S}|\mathbf{K}| \mathrm{A} \mathbf{A}|\mathbf{S} \mathrm{G}| \mathbf{H}$ \\
\hline GPR50 & 18 & $\mathrm{~L}|\mathbf{K}| \mathrm{PV}|\mathbf{s}| \mathbf{H}$ \\
\hline GPR50 & 25 & $\mathbf{S}|\mathbf{K}| \mathrm{PA}|\mathbf{S} \mathbf{G}| \mathbf{H}$ \\
\hline PR50 & 432 & $\mathrm{P}|\mathrm{K}| \mathrm{S} \mathrm{A}|\mathrm{T}| \mathrm{V} \mathbf{Y}$ \\
\hline GPR50 & 439 & $\mathrm{P}|\mathbf{K}| \mathrm{P} \mathrm{A}|\mathbf{s}| \mathrm{V} \mid \mathbf{H}$ \\
\hline GPR50 & 446 & $\mathrm{~F}|\mathbf{K}| \mathrm{AD} \mid \mathbf{S}$ \\
\hline PR50 & 3 & $\mathrm{~F}|\mathbf{K}| \mathrm{G} \mathrm{D}|\mathbf{S} \mathrm{V}| \mathbf{H}$ \\
\hline PR! & 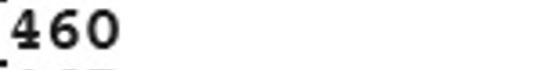 & $\mathrm{F}|\mathbf{K}| \mathrm{P} \mathrm{D}|\mathbf{S} \mathbf{V}| \mathbf{H}$ \\
\hline GPR50 & 46 & $\mathrm{~F}|\mathbf{K}| \mathrm{PA} \mid \mathbf{s}$ \\
\hline - parv & um_RNAPII & $\mathrm{Y}|\mathbf{S} \mathrm{P} \mathrm{T}| \mathrm{S} \mathbf{P}$ \\
\hline T & CTD_consensus & \\
\hline
\end{tabular}

Figure 3 Sequence alignment of human MT1, MT2 and GPR50 with bovine rhodopsin (pdb 1F88). Sequence identities are reported white on a black background, whereas sequence similarities are boxed (A). The positions of the transmembrane helices, as observed in the bovine rhodopsin structure, are reported above its sequence. Arrows indicate the positions of the amino acids that, in GPR50, evolved under positive selection. Stars indicate amino acids which have been shown to play a key role for melatonin binding in MT1 (dark blue), MT2 (light blue) or both (red). A ribbon representation of the GPR50 3D structure model is represented (B), with transmembrane helices colored according to the sequence alignment. Amino acids evolving under positive selection and amino acids important for melatonin binding in MT1/MT2 are shown according to the colors reported in the sequence alignment. 
mer figure six (figure 3) showed the GPR50 mouse sequence instead of the human sequence as stated in the legend [1].

\section{Author details}

'Physiologie de la Reproduction et des Comportements, UMR 6175 INRACNRS-Université François Rabelais de Tours-Haras Nationaux, 37380 Nouzilly, France. ${ }^{2}$ EA3781: Evolution Biologique - Laboratoire de PhyloGénomique Université de Provence - Marseille - France. ${ }^{3}$ Biologie Structurale, IMPMC, UMR7590, CNRS, Université Paris 6 et 7, 75015 Paris, France.

Received: 12 January 2012 Accepted: 7 March 2012

Published: 7 March 2012

\section{Reference}

1. Dufourny L, Levasseur A, Migaud M, Callebaut I, Pontarotti P, Malpaux B, Monget P: GPR50 is the mammalian ortholog of Mel1c: evidence of rapid evolution in mammals. BMC Evol Biol 2008, 8:105.

doi:10.1186/1471-2148-12-28

Cite this article as: Dufourny et al: Correction: GPR50 is the mammalian ortholog of Mel1c: Evidence of rapid evolution in mammals. BMC

Evolutionary Biology 2012 12:28.

\section{Submit your next manuscript to BioMed Central} and take full advantage of:

- Convenient online submission

- Thorough peer review

- No space constraints or color figure charges

- Immediate publication on acceptance

- Inclusion in PubMed, CAS, Scopus and Google Scholar

- Research which is freely available for redistribution

Submit your manuscript at www.biomedcentral.com/submit 